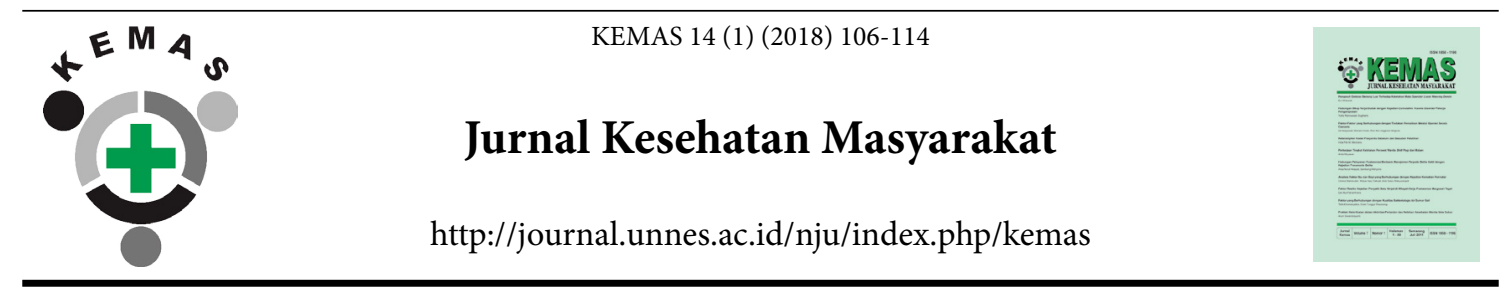

\title{
Children Under Five Year Mother Class Program to Detect the Children Growth and Development
}

\author{
Linda Meliati $^{1 \bowtie}$, Ni Putu Karunia Ekayani ${ }^{1}$ \\ ${ }^{1}$ Midwife Major, Health Ministry Polytechnic of Mataram, Indonesia
}

\begin{tabular}{l} 
Article Info \\
\hline Article History: \\
Submitted January 2018 \\
Accepted February 2018 \\
Published July 2018 \\
\hline Keywords: \\
Children Under Five Years \\
Mother Class, Knowledge, \\
Attitude, Growth and \\
Development Detection \\
\hline DOI \\
https://doi.org/10.15294/ \\
kemas.v14i1.12605
\end{tabular}

\begin{abstract}
This research objective is to analyze the effect of children under five year mother class program to mother's knowledge and attitude to detect the children growth and development. The research is dummy experiment with nonrandomized pretest posttest design. The research is applied to mothers having children age 0 - 59 months in Puskesmas (Community Health Service Center) Gunungsari work region as many as 30 persons. The result is there are improvement of average knowledge and attitude score after the class. Previous average score of the mothers knowledge is 0.33 point and attitude 1.8367 point. After one month of the class, average score of the mothers knowledge become 0.67 point and attitude 2.1334 point. Statistic test result that there is effect of children under five year mother class program in mother's knowledge and attitude to detect the children growth and development. There is no effect of the class implementation to mothers knowledge and there is effect of the class implementation to mothers attitude after one month intervention.
\end{abstract}

\section{Introduction}

Growing up means the addition of number and size of cells in all body organs. Developing is the getting complete of organ function that can be achieved through getting mature and learning process. Growth and development is a different process, both can not stand alone yet interconnected therefore it can be separated. Among the fastest time in children growth and development phase is whithin the first year of life thus the children should start be directed. The important period in children growth and development is on the infant period since it is the basic development that will affect and determent further development.
In this infant period, the development of lingua ability, creativity, social awareness, emotional, intelegence are very fast and become a base to next development process. The development of moral and personality also formed in the period, therefore every disorder no matter how small that undetected furthermore untreated will decrease that quality of the human resource on the future (Sulistiyawati, 2016).

The mother skill and role are very valuable to children growth and development process entirely since the parent can quickly recognize the advantages of the process and as early as possible give stimulation on children growth and development's aspects of phyisical, 
psychological and social. Stimulation is a motivation from the environment outside of the child. Infant growth and development are important to be attentioned by the parent, particularly the mother. Without parent guidance and attention, then the growth and development will not be going maximally.

The knowledge or cognitive is a very important domain to form someone attitude and habit. From the study, obtained that the attitude based knowledge lasts longer than one without knowledge, while someone knowledge will determine the integrality of the attitude. Therefore can be concluded that well knowledge of the mother can support the attitude in stimulating children under five growth and development (Notoatmodjo S, 2010).

The growth and development of each child does not same cause by many factors whether internal (genetical) or environmental (biological and psychosocial). Psychosocial factor affecting children growth and development is stimulation. Children with directed and well arranged stimulation will develop faster than they with less or not being stimulated (Lilik, 2014).

Based on this consideration, then it is necessary to educate the mothers related with children under five years growth and development detection through the implementation of Children Under Five Years Mother Class (KIB). KIB is opened for mother having children under five years (0-59 months). $\mathrm{KIB}$ is a study group activity in the class consists of several mothers having children under five years (0-59 months) under direction of one or several facilitator (instructor) using Mother Child Card (KIA) as learning tool (Kemenkes RI, 2011).

The objective of KIB is to improve the knowledge and skill, to alter an attitude and behavior of the mother regarding children under five years health, nutrition, children growth and development stimulation. Beside, KIB is a program to utilize KIA to improve mother and child health. The benefit is for the mother and her family. KIB is a way to obtain friend, question and obtain important information to be implemented. As for health attendant, the implementation of the class is to build stronger relation with children under five years mother, family and community.

The achievement of KIB program is affected by several factors like the facilitator that has been trained in children under five years mother class, facility and infrastructrure, motivation grouping or the mother based on children group age from 0-1 year, 1-2 years, and 2-5 years. Certainly, all those factors should support so that the children under five years program can be well implemented.

In Kabupaten Lombok Barat, the KIB implementation has been socialized since 2012. The Kabupaten Lombok Barat Health Office has trained the facilitator from each Community Health Service Centre (Puskesmas) representative, yet the KIB just effectively implemented since 2014.

In a study by Abdurahmah (2012), a research tittled nutrition education intervention in children under five years mother class program by giving micro nutrient substance to nutrition status improvement of malnutrition children under five years, it is said that the intervention in the KIB can give significant result since the mother group can focus to the material and guidance provided by the facilitator.

Based on Kabupaten Lombok Barat Health Office data, the target of children under five years in 2015 were 52,443 children and 2016 were 52,380 children. The Gunungsari Puskemas has most of the target with 4,683 children in 2016. The indicator of children under five years growth and evelopment detection implementation can be seen in the infant group and recorded in children under five years 1 and 2 report. The visit of children under five years 1 on Puskesmas Gunungsari in 2015 was 3,691 (83.43\%) and in 2016 was 4,343 (92.74\%) while in 2015 , the visit of children under five years 2 was 3,612 (81.65\%) and in 2016 was 4,272 (91.22\%).

Based on information from coordinator midwife of Puskesmas Gunungsari, implementation of children under five years mother class has been held since 2015. The class implemented each year does not take place on every village and arrange by refer to growth and development problem with many shortfall in the implementation. The class implemented in 2016 was taken place on Village Gunungsari, 
Jatisela, Midang, Tamansari and Kekait. The evaluation result of Puskesmas Gunungsari in 2016 was there were 15 children with growth and development problem from Village Sesela, Jati Sela and Kekait.

From interview with midwife from village health service (Poskesdes) Midang, in 2016 there were 3 children under five years growth and developmnent disorder case consisted of 1 down syndrome case and 2 cerebral palsy cases. The down sydrome case bring mortality of the child on age of 1 year, the cerebral palsy comes from preterm and severe pre eclamsia mother. The cerebral palsy found on Poskesdes Midang was referred to Puskesmas Gunungsari. The child then be re examinated and was referred to Lombok Care Foundation.

Based on above, there should be a research regarding the children under five years mother class program implementation effect on knowledge and attitude to detect growth and development on Puskesmas Gunungsari Kabupaten Lombok Barat work region in 2017.

\section{Methods}

This research is analytic with quasi experimental design with one group pretest and post test design and time series design using prospective data collection time approach. The research design does not use control group. In this research, the observation is conducted three times which are pre test before, after and a month after the treatment to find out the effect of class training intervention to the improvement of knowledge and attitude of children under five years mother on Puskesmas Gunungsari work region. The population in this research is mother having child ages 0-59 month on Puskesmas Gunungsari work region with data collection time period on June - September 2017 and 30 mothers sample through purposive sampling method as inclusion criteria.

The data collection is conducted by questionaire. It is distributed to each children under five years mother and return upon pre test of before the intervention. The questionaire is filled by the mother and guided by one instructor on the front that read the question one by one with supervision from the researcher, midwife coordinator and village midwife. The data collection regarding the knowledge and attitude of the children under five years mother is conducted 3 times which are before, after and one month after the class intervention.

The data analysis using computer statistic program and univariate analysis to view the frequence distribution, respondent characteristics, mother knowledge score before, after and one month after intervention. Bivariate analysis is used to analyze the effect of children under five year class program implementation to mother knowledge and attitude to detect the children growth and development. To verify the effect of class program implementation is done by Wilcoxon statistic test.

\section{Result and Discussion}

Research result shows that respondent characteristic based on mother age, most are 20-35 years old 28 respondents (93.3\%), distribution based on education most are elementary 19 respondents (63.3\%), distribution based on job most are housewife 25 respondents $(83.3 \%)$ while the working are as employee, merchant, entrepeneur and farmer. Result of respondent's characteristics frequence can be seen on Table 1.

Based on mother age characteristic, mostly are $20-35$ years old. This shows that the mothers are in reproductive period. Reproductive period is age period where a woman still able to be pregnant and giving birth. On these ages, it is expected that a mother does an active role in health program from puskesmas, so that the mother receives more health information, particularly regarding reproduction health, family welfare and mother and child health.

From education characteristic, it can be seen thaat most of the mother has elementary education. Mother education is one of the important factor since the higher someone education, the higher the knowledge, attitude and implementation. Low education causing the mother is difficult to receive information regarding children under five years growth and development detection.

Based on work characteristic, it can be seen that most of the mothers does not work or house wife. From the observation, the mothers attend the children under five years class program do not work, yet some who work as employee, merchant, farmer and enterpreneur attend the class. 
Regarding the frequence distribution based on information exposure and source of children under five years growth and development information and growth and development detection are presented on table 2 .

Based on table 2, from 30 respondents nearly most of children under five years mother get information regarding growth and development with 20 respondents $(66.7 \%)$ and 14 respondents (46.7\%) get information of growth and development with information source mostly from health attendant 20 respondents (66.7\%), peer (20\%), television, books, newspapers and magazines 3 respondents (10\%).

Information source can affect someone knowledge. Information obtained from formal or non formal education can give short term effect thus resulting a change or knowledge improvement. This is aligned with research

Table 1. Distribution of Respondent Characteristic Frequence on Puskesmas Gunungsari Work Region Year 2017

\begin{tabular}{lll}
\hline Characteristics & Number & Percentage \\
\hline Age & & \\
$<20$ years & 0 & 0 \\
$20-35$ years & 28 & 93.3 \\
$>35$ years & 2 & 6.7 \\
Total & 30 & 100 \\
Education & & \\
Uneducated & 1 & 3.3 \\
Elementary (SD/SMP/equal) & 19 & 63.3 \\
High School (SMA/equal) & 5 & 16.7 \\
Graduate (Diploma/Bachelor/Doctor) & 5 & 16.7 \\
Total & 30 & 100 \\
Work & & \\
Does not work & 25 & 83.3 \\
Work & 5 & 16.7 \\
Total & 30 & 100 \\
\hline Source: Primary Data &
\end{tabular}

Source: Primary Data

Table 2. Frequence Distribution Based on Information Exposure And Source of Children Under Five Years Growth And Development Information And Growth And Development Detection

\begin{tabular}{lcccc}
\multicolumn{1}{c}{ Kind of Information } & \multicolumn{3}{c}{ Obtain Information } \\
\hline Knowledge & Yes & $\%$ & No & $\%$ \\
Children Under Five Years Growth\&Development & 20 & 66.7 & 10 & 33.3 \\
Growth\&Development Detection & 14 & 46.7 & 16 & 53.3 \\
Source & & & & \\
Peer & 6 & 20 & 24 & 80 \\
Parent & 2 & 6.7 & 28 & 93.3 \\
Traditional Healer & 1 & 3.3 & 29 & 96.7 \\
Health attendant & 20 & 66.7 & 10 & 33.3 \\
Radio & 1 & 3.3 & 29 & 96.7 \\
Television & 3 & 10 & 27 & 90 \\
Books, Newspapers, Magazines & 3 & 10 & 27 & 90 \\
Internet & 0 & 0 & 0 & 0 \\
\hline Source: Primary Dat
\end{tabular}

Source: Primary Data 
Table 3. Distribution Children Under Five Years Mother Before, After and A Month After Children Under Five Years Mother Class Program Implementation

\begin{tabular}{|c|c|c|c|c|c|}
\hline Variable & Mean & Median & SD & $\begin{array}{l}\text { Min - } \\
\text { Max }\end{array}$ & $95 \%$ CI \\
\hline \multicolumn{6}{|c|}{ Before Class Program Intervention } \\
\hline Knowledge & 7.67 & 8.00 & 0.994 & $5-9$ & $7.30-8.04$ \\
\hline Attitude & 31.43 & 32 & 2.750 & $26-36$ & $30.41-32.46$ \\
\hline \multicolumn{6}{|c|}{ After Class Program Intervention } \\
\hline Knowledge & 8.00 & 8.00 & 0.947 & $6-9$ & $7.65-8.35$ \\
\hline Attitude & 33.2667 & 35.5000 & 3.34183 & $28-36$ & $32.0188-34.5145$ \\
\hline \multicolumn{6}{|c|}{ One Month After Intervention } \\
\hline Knowledge & 7.33 & 8.00 & 1.348 & $4-9$ & $6.83-7.84$ \\
\hline Attitude & 31.1333 & 31.0000 & 3.15937 & $21-36$ & $29.9536-32.3131$ \\
\hline
\end{tabular}

Source: Primary Data

result indicating that there is significant effect of training class to children under five years mother in growth and development detection compare to mother that never being trained.

From table 3 can be seen that there is improvement in knowledge and attitude score before and after intervention. After intervention, averagely the knowledge is improved 0.33 poin while attitude is improved 1.8367 point. After one month of intervention, there are a decrease of knowledge 0.34 point and attitude 0.2967 point.

In one study (Abdurahmah, 2012) obtained that the functional group discussion has positive effect on mother knowledge improvement regarding children under five years growth and development. It is indicated from $t$ test result with $p$ value $(0.000)<0.05$ and average mother knowledge score is improved from 11.94 to 15.78 . The mother knowledge regarding children under five years will improve after the training by functional group discussion method. Since through this method, the mother is given an opportunity to express the thought and encourage each individual to think and take a decision. Beside that, the mother is encouraged to solve the problem regarding topic of discussion that make each individual to develop an idea to provide health problem solving alternative in given training material.

One of an effective way to improve mother attitude in a child growth and development detection is by providing useful information, whether through mass media or local health attendant regarding the importance of it thus there will be an updated understanding and mother's way of think improvement.

Environment or culture can has large effect on someone personality since it implants our respond to various problems. Therefore, personal experience will form and affect our understanding to social stimulus as well. Then it will form whether a positive or negative attitude, depend to other factors.

Based on a study (Sri \& Endang, 2014) obtained that average attitude score improvement on children under five years mother class is lower than group who follow the children under five years class but does not significant. Eventough based on the percentage, there are attitude score improvement on both group.

Based on o Signed Rank Test result, the $p$ value is 0.032 , then on alpha $5 \%$ can be seen that there is effect of children under five years mother class program implementation to mother knowledge in growth and development detection on Puskesmas Gunungsari Kabupaten Lombok Barat work region in 2017. The effect is significant between mother knowledge before and after program training. The result of this research is as expected by government in setting the objective of mother class implementation. The class is designed to facilitate common learning regarding children under five years health through improvement of mother knowledge, attitude and behavior in understanding of child development, stimulation and growth and development detection of the children under five years (Kemenkes RI, 2011). Any information 
obtained by the mother on children under five years mother class will be useful to detect growth and development disorder.

From a research (Mahmudah et al., 2015) obtained that there is improvement of average cadre knowledge and action score after training. The cadre knowledge score was improved as many as 2.428 points and action score to 1.071 point after the training. The statistic test result with Paired T Test obtained significant different on cadre knowledge and action before and after children under five years development monitor training. This means there is effect from the training to cadre knowledge and action in evaluates and monitor children under five years development. This is aligned with a research (Ningtyas, 2017) said that there is effect of children age 0-59 months mother class to the knowledge of KIA book usage, also aligned with a research (Sulistiyawati, 2016) said there is a relation between mother knowledge and attitude in malnutrition children under five years growth and development stimulation ability on Puskesmas Galur II Banaran Village, Kulon Progo, Yogyakarta. And aligned with a research by Kartikawati et. al. obtained that children under five years mother class has effect on the improvement of knowledge, attitude and skill of the mother in take care the child.

The result is different than one (Adevia \& Budi, 2016) obtained that the improvement of mother knowledge, attitude and behavior in parenting on Mother (Bunda) SMS Program is more effective than mother class program.

The knowledge different before and after the training is caused by several factors, like mother characteristics consist of age, education or other factors like training proces. This research result is aligned with a theory that external factor or factor from outside of the individual like a training has effect to the improvement of knowledge. Mother can memorize the material delivered by facilitator and in term of knowledge means able to remember an information, material or other stimulus received (Notoadmodjo, 2010).

This can be caused by along the class training, the mother can get information, interact and share any experience among the mothers or with the facilitator/midwife regarding children under five years growth and development detection. For the respondents obtaining below average points can be caused by lack of information and misinterpreted the information obtained during the class.

Knowledge improvement in this research is one of mother class training indicator, which in it there is learning activity of cognitive aspect, through sequenced information transformation in respondent self. When related to Bloom (1908) in Notoatmodjo (2010) based on the characteristics of receptor, sensory register, STM, LTM are identic with cognitive aspect, generator respond is identic with affective and effector is identic with psychomotoric. According to Notoadmodjo (2010) stating that behavior that based on knowledge will last longer compare to behavior without knowlede.

From Wilcoxon Signed Rank Test, obtained that there is not significant effect between mother knowledge after the training and after one month of the training with $\mathrm{p}$ value $=0.063(\mathrm{p}>0.05)$.

This is indicated that by attend the children under five years mother class knowledge obtained regarding development, stimulate development and growth and development detection still be memorized well thus in evaluation by KIA book, the mother able to point her child growth and development correctly. The well memorized can be caused by many aspect. Like repeating previous training material and previous pre and post test result, the usage of communication media/APE in class implementation, some mothers maintain communication by phone or when took her child ask about unclear things in the class. Beside, the mether can read again the material in KIA book to be discussed with her family.

Based on a research (Ima, 2017) obtained that the mother knowledge and skill in stimulating children under five years growth and development soon after the training increase on intervention group yet does not on control group. A month after the training there is a decrease in knowledge and skill to stimulate growth and development in both group. The improvement of mother knowledge and skill in stimulating children under five years soon after the training on intervention group become higher and decrease one month after the training become lower than control 
group. Factors like individual learning, learning material, training room arrangement become an obstacle in child growth and development early detection training.

This result is different with other research (Wirawan et al., 2014) mentioned that there is different of mother average knowledge (post test) after the counseling with $\mathrm{AV}$ media compare to control group and there is effect of mother average knowledge improvement between before and after the counseling program by whether AV or conventional media

From the presence of communication with the environment, it is expected that there will be behavior improvement followed by family and community environment improvement. This is aligned with Notoadmodjo (2010) that note the health promotion is a behavior alteration program, yet also followed by environment change. Since the behavior change without environment change will not be effective and will not last long. Thus health education through children under five years mother class is one of method to improve the knowledge, managed and more optimum as one of safe motherhood pillar to decrease mother and child mortality rate.

From Wilcoxon Signed Rank Test obtained that there is effect of mother class program implementation to mother attitude in detecting the child growth and development on Puskesmas Gunungsari Kabupaten Lombok Barat work region in 2017 ( $\mathrm{p}$ value $=0.040$ ). This indicates that children under five years mother class training given is highly beneficial to improve positive attitude in detecting children under five years growth and development.

From the research shows that attitude improvement after mother class program intervention, like a research (Sri \& Endang, 2014) resulting there is a change of mother attitude in taking care of her child ( $\mathrm{p}=0.001)$.

Attitude is an affirmation of thinking process, it is emotional or affection and if there is a change, it should be caused by a strong and influential need. The researcher assume that health education is a stimulus affecting individual mind set or attitude. By the presence of mother knowledge improvement on children under five years growth and development detection, then there will be a positive attitude improvement to mother ability to monitor the child growth and development.

This is aligned with a research (Nurchairina, 2014) obtained that there is relation between mother stimulation and children under five years development. The fisher exact statistic test results p value $=0.044$, means there is significant relation between stimution and children under five years development. From analysis result, obtained the OR valu 4.593 means mother giving well stimulation has 4 time opportunity to have her child develop as age group.

From attitude change theory from Kelman emphasizes social process that highly affect the attitude change. There are 3 social processes play role in attitude change which are willingness, identification and internalisation. The willingness in this case is individual willingness or the mother to accept other people, which are facilitator or the group, influence. This willingness occasionally does not emerge from the conscience just to get positive reaction. Moreover, the facilitator in the class is someone who has not been known before. The mutual trust relationship will be created when two persons have had emotional relation. The identification process will take process when the individual in this case the mother imitate the attitude expected by the group when the individual believe that the change taken will give better effect as individual expectation.

This processes required quite long time. The children under five years mother class implementation that only take time 3 months and regularly conduct monthly has not sufficient to actualize the willingness and identification process. Internalisation is an individual process receives the affect due to the attitude is aligned with consciousness and value sistem believed. The interaction of those three process is attitude change mechanism that highly depended from the party influencing the individual and various condition controlling the process of affect and implication to attitude change.

From Wilcoxon Signed Rank Test obtained that the attitude one month after the training there is significant effect on mother attitude after follow the training and one month after the training (nilai $\mathrm{p}=0.030$ ). This indicates that attitude after the training and one month 
after the training does not different, where both has significant effect.

On a research (Manurung, 2015), obtained that mother knowledge determines mother attitude. This is due to mother knowledge has relation with attitude of nutrition fulfillness. The information regarding nutrition fulfillness on children under five years will improve mother knowledge and the process, since mother knowledge hold an important role to determine the attitude in children under five years nutrition fulfillness.

From the research that the mother class affect the knowledge and attitude improvement, this is aligned with the objective of the class, which is to improve the knowledge and attitude in children under five years growth and development detection. The improvement of knowledge and attitude is related. There are many factors affect the achievement of a health training or education. Though health promotion with children under five years mother class method provide more material to learn and possibility of maximum material development as available and can be implemented along with the posyandu activity.

Children under five years mother class implementation has a weakness when the facilitator can not translate the experience and knowledge of the member to learning material, then the learning process will not be interesting. Other weakness are the member can be taken to conventional counseling situation and the facilitator become such as lecturer in a larger class, a skilled facilitator is required, high implementation cost and when there is limited learning material then the member will less able to develop training material.

\section{Conclusion}

Based on the research result can be concluded that the children under five years mother implemented on three village (Village Sesela II, Kekait II and Guntur Maan) in Puskesmas Gunungsari work region affect the improvement of children under five years mother knowledge and attitude in detecting growth and development significantly.

It is advised that every Puskesmas to implement such class as routine activity like integrated health service post (posyandu) and direct the activity as community initiative, to implement and develop mother class on each work region and always improve the knowledge to be able to provide quality health service to the community.

\section{Reference}

Abdurahmah, L., 2012. Pengaruh Metode Diskusi Kelompok Fungsional Terhadap Pengetahuan Ibu Tentang Tumbuh Kembang Balita (Studi Kasus Di Posyandu Margirahayu IV Desa Pekalongan Kecamatan Bojongsari Kabupaten Purbalingga. Unnes Journal of Public Health, 1(2), pp. 1-7.

Adevia, M.C., \& Budi, L.A.Y., 2016. Efektivitas SMS Bunda Dibanding Kelas Ibu Balita Terhadap Peningkatan Pengetahuan, Sikap, Perilaku. Public Health Perspective Journal, 1(1), pp. 21-28.

Ima, S.M., 2017. Pengaruh Pelatihan Stimulasi Deteksi dan Intervensi Dini Tumbuh Kembang Anak. Prosiding Seminar Nasional \& Internasional, pp.101-106.

Kemenkes, R.I., 2011. Pedoman Pelaksanaan Kelas Ibu Balita, Kementrian Kesehatan RI. Jakarta.

Lilik, H.A.K., 2014. Hubungan Pengetahuan Ibu Tentang stimulasi Tumbuh Kembang Balita Dengan Perkembangan Balita Usia 12 - 36 bulan di Posyandu Kasih Ibu 7 Banyu Urip Klego Boyolali Tahun 2014, Ilmu Kesehatan Anak Dalam Kebidanan. Trans Info Media, 6(1), pp. 83-100.

Mahmudah, U., Cahyati, W.H., \& Wahyuningsih, A.S., 2015. Pengetahuan dan Tindakan Kader Posyandu Dalam Pemantauan Pertumbuhan Anak Balita. Jurnal Kesehatan Masyarakat, 11(1), pp. 65-73.

Manurung, S.S., 2015. Hubungan Pengetahuan Ibu Dengan Sikap Dalam Pemenuhan Nutrisi Pada balita (0 - 5 Tahun) di Dusun Rejo Sari Desa Kwala Begumit Kecamatan Stabat Kabupaten Langkat tahun 2012. Ilmiah Keperawatan, 1(1), pp.1-7.

Ningtyas, S.F., 2017. Pengaruh Kelas Ibu Balita Usia 0-59 Bulan Terhadap Pengetahuan Pemanfaatan Buku Kia. Jurnal Keperawatan Dan Kebidanan, 8(1), pp. 63-71.

Notoatmodjo, S., 2010. Promosi Kesehatan dan Ilmu Perilaku. Rineka Cipta. Jakarta

Nurchairina, N., 2014. Pemberian Stimulasi Oleh Ibu Untuk Perkembangan Balita. Jurnal Keperawatan, X(1), pp.138-143.

Sri, L.K., \& Endang, S.D.D., 2014. Pengaruh Kelas Ibu Balita Terhadap Peningkatan Pengetahuan, Sikap, Dan Keterampilan Ibu Balita Dalam Merawat Balita di Wilayah Kerja Puskesmas Sukarasa Kota Bandung. Jurnal Bakti 
Kencana Medika, 4(1), pp.26-32.

Sulistiyawati, H.P., 2016. Pengetahuan Berhubungan dengan Sikap Ibu dalam Kemampuan Menstimulasi Pertumbuhan dan Perkembangan Anak Balita dengan Gizi Kurang. Jurnal Ners dan Kebidanan
Indonesia, 4(2), pp.63-69.

Wirawan, S., Abdi, L.K., \& Sulendri, N.K.S., 2014. Penyuluhan Dengan Media Audio Visual Dan Konvensional Terhadap Pengetahuan Ibu Anak Balita. Jurnal Kesehatan Masyarakat, 10(1), pp.80-87. 